\title{
Editorial Foreword
}

CAPITALIST TRANSFORMATIONS OF AGRICULTURE. The question of what capitalism does to farming remains controversial. The complicated findings of energetic and careful research-for we know a lot-and the flinty independence of individual scholars account for some of that, but there are two other important reasons for the intensity of these discussions. First, the question is crucial to arguments about the transition to capitalism and the adaptability of peasant communities, important topics that require the testing of fine distinctions (and ones especially critical for Latin America-see Winson in CSSH 25:1; Forman and Riegelhaupt, 12:2). Any conclusions are likely to define an historical process and what (if anything) in that process is universal. Such issues are crucial to theories of development, to Marxist interpretations, to ideas about the effects of markets, and to conceptions of a world-capitalist system. At the same time, these topics evoke a particular view of precapitalist society, of what a peasant is (or was), and of how peasant communities are held together or their bonds eroded (topics previously discussed in $\mathrm{CSSH}$ by, among others, Somers and Goldfrank, 21:3; Rambo, 19:2; Skinner, 13:3). Second, in the forty years since World War II, networks of commerce and communication have vastly expanded, reaching into even the most isolated societies, where social scientists have scurried to study the changes taking place (see, for example, Weingrod and Morin, 13:3). These more detailed and more diverse findings in turn challenge older theoretical and comparative frameworks.

Some provocative surprises can result when theory and local studies are brought together in an analysis as precise as David Lehmann offers. Wage labor, he argues, is not what distinguishes a capitalist family farm from a peasant farm, where paying wages may be either cheaper or more expensive than the labor acquired through family ties or reciprocal exchanges (points supported by the work of Rothstein, 28:2, and Friedmann, 20:4). His comparison of regions in Equador, Peru, and Chile is used both to exemplify theoretical distinctions and to suggest that under different conditions the arrival of capitalism can lead to quite different outcomes for peasant farming. This emphasis upon the effect of local conditions leaves room for emphasizing the adaptive rationality of peasants and for a certain optimism about the potential effects of capitalism. Timothy Keegan also challenges some familiar assumptions, noting the limited penetration of either colonial rule or capitalism into the farms of South African Boers. Like Lehmann, he finds that sharecropping need not always have all the regressive effects conventionally associated with it - in South Africa he sees it as having been a means of transition during the early stages of industrialization-and he, too, argues that peasant farming (and labor based on kinship) can make sense in a capitalist world and that the form of capitalist development is contingent. The findings that result from 
Jane Collins's extensive field work in Peru are also largely consonant with Lehmann's, but her target is quite different. She criticizes the concept of the household as ethnocentric, the original sin of anthropology. (On households, see Roberts, 26:2; Sanjek, 24:1; Kuznesof, 22:1; Hammel and Laslett, 16:1.) Capitalism, she finds, makes use of precapitalist social relations while undermining them. Ecological determinants, which emerge as particularly important in Collins's study, are directly tested in J. S. Otto and N. E. Anderson's neat comparison of cattle raising in Florida and Venezuela, where similar responses to the Cuban market need to be explained.

PERSPECTIVES ON THE POSITION OF WOMEN. The first generation of women's studies has had one great advantage even while having to contend with the skepticism of colleagues and great areas of missing knowledge. That advantage is the fresh insight that comes from a different point of view, the shock of recognition as feminist perspectives prove applicable to any topic involving human relations. Given this breadth, no one method or set of problems predominates. Thus, in assessing the politics of women's suffrage in Japan, Sharon Nolte must consider cultural attitudes toward women as well as political practice, while weighing the experiences common to all women against class differences, a lively issue for women's studies everywhere (Ross and Rapp, 23:1; Rogers, 20:1). Comparison can be a great help, but one must choose what to compare: the women's movement with other aspects of Japanese experience (see Smith, 26:4; Wilson, 25:3; Hall, 5:1), Japanese society and similar Asian societies, or the movement for women's suffrage in Japan with the same movements elsewhere, especially in the United States. Opting for this last, Nolte comes to highlight differences between the two countries in the social position of women, in political systems, and in the role of the state. As the review essays in this section demonstrate, the perspectives of women's studies range broadly and can raise radical questions about the nature of an historical era or a major revolution.

SLAVERY AND CLASS. Slavery and the labor systems that follow its abolition are topics nowadays nearly always treated in comparative terms, and that leads of course to questions of social class (note Graham, 23:4; both Hill and Strickland, 18:3; Sio, 7:3; and Degler, 2:1). These issues have been emphasized in histories of Caribbean countries especially. Taking up an earlier discussion in CSSH (Bolland, 23:4; see also Scott, Green, and Bolland in 26:1), Howard Johnson finds that in the Bahamas debt was used (like scarcity of land elsewhere in the West Indies) as the basis for a system of compulsion that made proletarianization an emancipation. The relationship of slavery to indebtedness or systems of production is by no means a settled question, however, as the essays on recent studies of slavery in ancient Greece, Russia, and the new world make clear. 